Umantsiv Iurii,

Doctor of Sciences (Economics), Kyiv National University of Trade and Economics,

Kyiv, Ukraine

ORCID 0000-0003-0788-7110

ResearcherID N-7018-2016

Nikolaiets Kateryna,

Doctor of Sciences (History), Kyiv National University of Trade and Economics,

Kyiv, Ukraine

ORCID 0000-0002-0471-2895

ResearcherID O-3726-2016

\title{
TRANSFORMATION OF THE GOVERMENTAL ROLE IN ECONOMY IN TERMS OF GLOBALIZATION
}

The theoretical and methodological principles of transformation of the role and place of the state in the regulation of economic processes are researched. The main directions of changing the economic role of the state in the conditions of globalization are revealed. The attention is focused on the need to find a balance between the possibilities of market self-regulation and the influence of the state on the course of economic processes.

Keywords: state, regulation, market, globalization.

Уманців Юрій, Ніколаєць Катерина. Трансформація ролі держсави в економіці в умовах глобалізації.

Досліджено теоретико-методологічні засади трансформації ролі та місия держави у регулювання економічних процесів. Розкрито основні напрями зміни економічної ролі держави за умов глобалізації. Зосереджено увагу на необхідності пошуку балансу між можливостями ринкового саморегулювання та виливом держави на перебіг економічних процесів.

Ключові слова: держава, регулювання, ринок, глобалізачія.

Relevance of research topic. Deep social transformations in the late XX-early XXI century require a proper theoretical understanding of such processes. Approved representations do not give scientists the opportunity to make a proper scientific analysis of a complex of methodological problems, to evaluate the logic of deployment of new processes and to determine their inner essence. It is about the need for a 
critical rethinking of the prevailing theories and the formation of new conceptual and paradigmatic approaches to the study of transformational shifts. In this case, the methodological basis needs to be given special attention; it is capable of ensuring the disclosure of the essential prerequisites for the transformation of the relation between state influence on economic processes and market self-regulation [6, p. 7-8].

Formulation of the problem. Understanding the fundamentals of knowledge accumulation allows us to find out contradictions and to expand understanding of the complex process of crises occurrence in the methodology of individual trends, concepts and models. On the basis of contradictions elimination between the pace of changes in the content of economic processes and the transformation of theoretical justification, between the integrity of economic theory and its separate areas of research, there is a necessary basis for the emergence of such vectors of economic knowledge development because of systematization of accumulated theoretical achievements. Economic theory is now at the next stage of the accumulation of new ideas for the transition to the next stage of its development. Under such conditions of global transformation, a large number of contradictions of previous periods disappears, and at the same time many differences between different directions of world economic thought are eliminated. New directions, while keeping in touch with the ideas previously formulated, are largely aimed at synthesizing approaches within the main areas of economic science.

Analysis of recent research and publications. The analysis of a wide range of issues related to the disclosure of the content and directions of the state's economic policy is devoted to the work of such researchers as L. Correia, Y. Gorodnichenko, G. Roland, A. Grytsenko, O. Grytsenko, H. Faria, H. Montesinos-Yufa, V. Kozyuk, S. Korablin, P. Martins, D. Morales, C. Navarro, R. Reich, A. Sirko, T. Piketty, R. Sharma and many others. However, the problem of transforming the role of the state in the economy in a globalizing environment requires deep scientific research.

Presenting main material. Global development at the beginning of the XXI century was marked by the deployment of a new stage in the development of the state as a social institution, due to political transformation and economic adaptation to the newest conditions. In the context of globalization processes, traditional functions and the role of the state in the system of economic relations are transformed. It can be argued that the institutional balance is shifting from market-based self-regulators to the state institution, which plays a system-forming role in socio-economic development. At the heart of considering the advantages and disadvantages of state intervention in the economy is basically its opposition to the market. At the same time, the state and the market do not deny, but just complement each other. Taking into account the externalities of the market economy, it should be noted that the state and the market form a solid foundation for the functioning of the modern economy and society in general (Figure 1). A modern, efficient state is characterized primarily by the quality 
and sustainability of institutions that provide effective market coordination with the least transaction costs. To a large extent, it is the excellence of the institutions that determines the social choice and direction of state regulation of the economy [6, p. 9].

Ensuring sustainable economic growth and achieving the goals of social development are in the plane of combination of levers of economic policy of the state and market self-regulation. For the scientific community, it's obvious that today the problem of the relationship between the state and the market should not be formulated in the context of the greater or lesser participation of the state in the economy. Under current conditions, the market and the state perform their inherent functions, mutually supplemented and balancing one another. On this basis, you can simultaneously increase the role of the state in the economy and develop market mechanisms. Therefore, instead of a liberal approach, in which less is the state in the economy, then better, and the principle of ungrounded growth of the role of the state, one should proceed to the approach, according to which there should be «more state and more market». Under these conditions, the market primarily implements private interests, and the state defends the aspirations of society as a whole. In this regard, for Ukraine, such a priority is the transformation of the economic system, which would simultaneously rely on the liberalization and deregulation of the economy, and used the potential of market mechanisms and the state's ability to eliminate structural deformations for the purpose of dynamic and balanced development [4, p. 20].

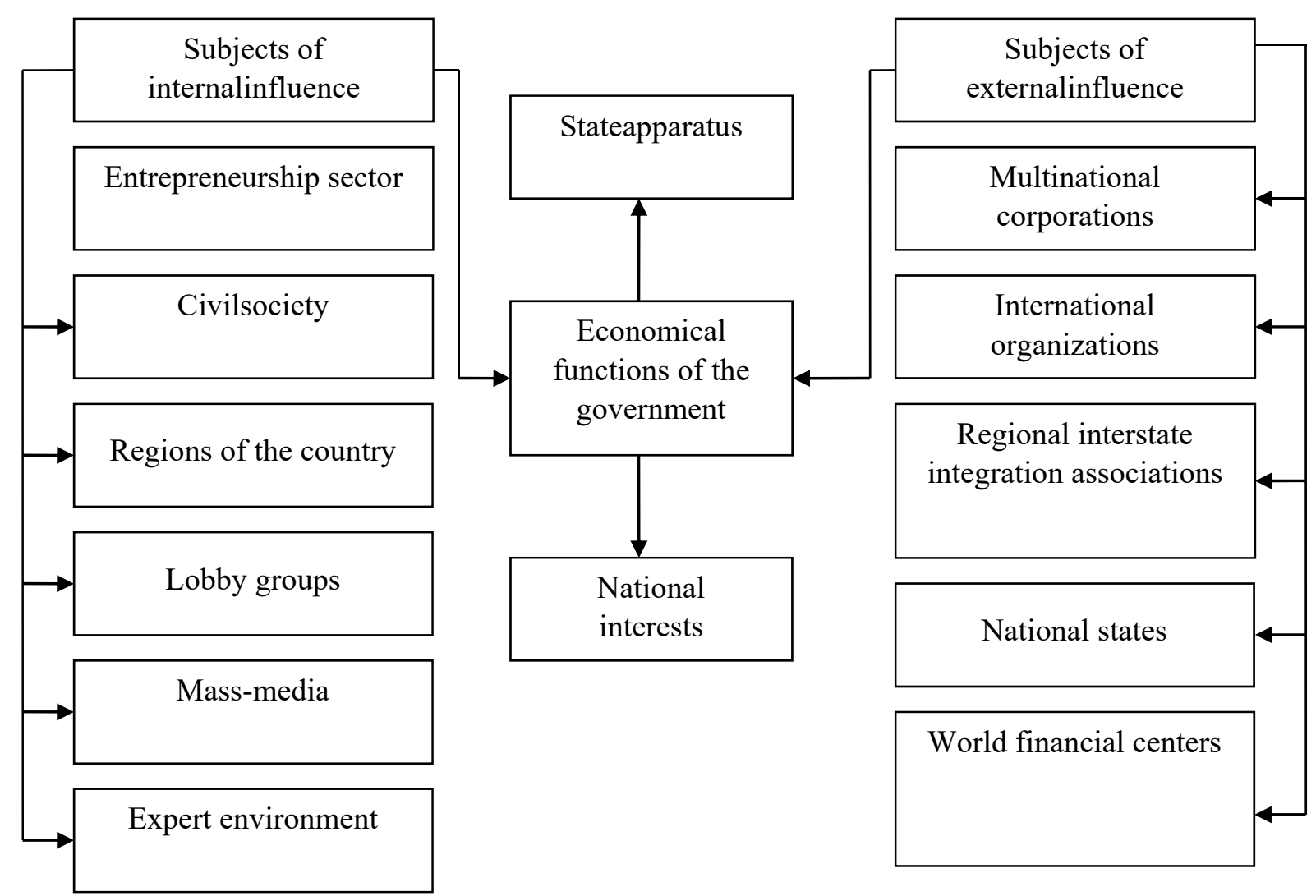

Figure 1. Subjects of influence on the economic functions of the state 
On the basis of the institutional paradigm of the analysis of socio-economic development, one can conclude that one of the biggest problems of Ukraine is the destructiveness of market institutions and state regulation of the economy. These components themselves impede the implementation of deep and radical transformations, and therefore cause the accumulation of various imbalances and conservation of imperfect model of economic development [10, p. 17; 3, p. 404-408]. S. Korablin advocates a similar position, pointing out that the role of the state in the economy should be substantial. The most important issue at the same time is not related to the scale of the state, but with specific directions and methods of its impact on the course of economic processes. The scientist gives the experience of developed countries, in which the sphere of responsibility of the state is rather broad [5, p. 54].

Argues the idea that «both anti-market and anti-state approaches are partially correct», T. Picketti. The scholar convinces that new instruments of state interference in the economy are necessary [7, p. 480]. In this context, R. Reich argues that the existence of markets depends on the rules governing property relations, the level of market monopolization, contracts and bankruptcy rules. Obviously, such rules are not natural law, and for their functioning they must be approved by a certain institution. Over the past decades, these rules have undergone a change, as large corporations and richest individuals have a greater influence each time on those political institutions that are responsible for adopting such rules. The scientist notes that there is no «free market» without the government, because such a market does not exist outside the influence of civilization. It is a matter of the fact that civilization is determined by rules, and the markets themselves are created by such rules, which in turn are developed by governments [8, p. 22].

It is just a market that requires the government to introduce and adhere to clear rules, and therefore the government not only interferes with the free market but also creates it. Such market rules are not constant because societies at different times adopted their various variants, which to some extent reflect the evolution of the norms and values of society, but also demonstrate which institutions are able to establish rules. The rules for the functioning of the free market have a much greater impact on the economy and society, since it is impossible to have a market system without the rules and choices that are guaranteed by such rules [8, p. 22].

Consequently, precisely because of this, according to R. Reich, «free market» is a myth that hinders the study of changes in the rules of functioning of the economy. Subjects of unfair influence on market rules are the main beneficiaries of how these rules are developed and adapted to economic conditions. That is why these actors are the most active supporters of the «free market» and advocate an opinion on the relative superiority of the market over the government. Advocates of the "free market» demand not only to agree with them on the issue of its advantages, but also to recognize the need for a permanent discussion on this issue [8, p. 23]. The modern market should be regarded as a non-equilibrium dynamic system in which equilibrium 
is, in most cases, an exception than the rule of its existence. At present, there is a deep systemic reconstruction of the most important functions of the state, which is associated with globalization processes and the development of the information society [1].

Under conditions of global competition, the economic functions of the state are substantially modified, which is expressed not only in the revision of the conceptual and methodological principles of state regulation theory, but also in the change of its directions, forms and methods. It is said that the intergovernmental system of regulation gives way to the conditions under which the borders and borders of the state overcome the global character of modern markets. Obviously, the role of the state is essentially changing under the influence of globalization, and the conclusion about reducing its regulatory role is not very justified. Taking into account the loss of state due to the globalization of some of its functions, attention should be paid to the gradual strengthening and modification of forms of state intervention in economic processes [9, p. 110-118].

In this regard, not only theory, but also practice shows a decrease in the effectiveness of the actual market mechanisms, which is confirmed by the course of the global financial and economic crisis of 2008-2009 and huge losses of the world economy. That is why the world economy is at the threshold of a significant strengthening of the role of the state. Under these conditions, the discourse of world development moves to the format «man - the state - a global society». To a number of traditional problems are added such pressing challenges as enormous volumes of migration, global economic problems, the growth of manifestations of terrorism. Changing its functions, the state remains the basic construction of a new global architectonics [2, p. 110-118]. Avoiding the systematic recovery of crisis phenomena will depend on the duration and depth of the risks of macroeconomic imbalances.

Conclusion. An important task in the theoretical and methodological aspect is the rethinking of the new challenges faced by the world economy. Discussions on the prospects of development should take place in the direction of theoretical substantiation of the formation of effective regulatory mechanisms, harmonization of which at all levels will ensure the prerequisites that will further minimize the risks of violations of the stability of the world economy. The role of the state in the conditions of modern transformations is conditioned primarily by the fact that the state is considered as an entity that ensures the reliable functioning of all elements of the socio-economic system. Speaking as a representative of society as a whole, the state establishes the rules for the functioning and interaction of economic entities within a certain order and monitors their compliance.

The basis for the implementation of the regulatory influence of the state should be the scientific identification of the strategic priorities of economic development and the definition of conceptual approaches and tools on this basis in order to harmonize the interests of society. The conducted research has revealed a number of factors that are often not taken into account in many areas of theoretical economic science, which 
is a significant incentive for conducting scientific research in this direction. A promising vector for further research is the definition of the prospects for the synthesis of various theoretical approaches in order to reach the new trajectory of knowledge of socio-economic transformations.

\section{REFERENCES}

1. Correia, L., Martins, P. (2019). The European crisis: Analysis of the macroeconomic imbalances in the rescued euro area countries. Journal of international studies. Vol. 12. № 2, 22-45. [in English].

2. Faria, H., Montesinos-Yufa, H., Morales, D., Navarro, C. (2016). Unbundling the Roles of Human Capital and Institutions in Economic Development. European Journal of Political Economy. № 45, 108-128 [in English].

3. Gorodnichenko, Y., Roland, G. (2017). Culture, Institutions, and the Wealth of Nations. Review of Economics and Statistics. Vol. 99. Issue 3, 402-416. [in Ukrainian].

4. Grytsenko, A., Grytsenko, O. (2019). Osoblyvosti suchasnoi kryzy v Ukraini: lohiko-istorychnyi pidkhid [Peculiarities of the current crisis in Ukraine: a logical and historical approach]. Ekonomichna teoriia ta pravo - Economic Theory and Law. №1, 11-26. [in Ukrainian].

5. Korablin, S. (2017). Makroekonomichna dynamika Ukrainy: pastka syrovynnykh rynkiv [Macroeconomimics dynemics of Ukraine: the trap of raw materials market]. Kyiv, Institute of economics and foreseeing of National Scintific Acedemy of Ukraine, 308. [in Ukrainian].

6. Koziuk, V., Haida, Yu., Shymanska, O. (2019). The government typology of satisfaction, the quality of institutions and ecology in post-Soviet Union countries. Journal of European economy. Vol. 18. № 1, 3-19. [in Ukrainian].

7. Piketty, T. (2014). Kapital v dvadzat pershomy stolitti [Capital in the twentyfirst century]. Kyiv: Nash format, 696. [in Ukrainian].

8. Reich, R. (2018). Spasti kapitalizm: dlyua bagatoch ne dlya deyakux [Saving Capitalism: For The Many, Not The Few]. Kyiv: Nash format, 288. [in Ukrainian].

9. Sharma, R. (2016). The Rise and Fall of Nations Forces of Change in the Post-Crisis World. W. W. Norton\&Company, NY, London, 480. [in English].

10. Sirko, A. (2019). The problem of the quality of Ukraine's economic growth: theoretical approaches and policy routines. Bulletin of the Ternopil National Economic University. № 1, 7-20. [in Ukrainian]. 